\title{
Reduction of cadmium availability to tobacco (Nicotiana tabacum) plants using soil amendments in low cadmium-contaminated agricultural soils: a pot experiment
}

\author{
Catherine Keller ${ }^{1,2,5}$, Monica Marchetti ${ }^{1}$, Luca Rossi ${ }^{3,4}$ and Nicolas Lugon-Moulin ${ }^{3}$ \\ ${ }^{1}$ Ecole Polytechnique Fédérale de Lausanne, ENAC - ISTE - Laboratory of Soil Science, Station 2, 1015 , \\ Ecublens, Lausanne, Switzerland. ${ }^{2}$ Present address: CEREGE, Université Aix-Marseille III, Europôle \\ Méditerranéen de l'Arbois, BP 80, 13545, Aix-en-Provence, Cedex 4, France. ${ }^{3}$ Philip Morris International \\ R\&D, c/o Philip Morris Products SA, 2000, Neuchâtel, Switzerland. ${ }^{4}$ Present address: Philip Morris USA, \\ RD\&E Department, P. O. Box 26583, Richmond, VA, 23261, USA. ${ }^{5}$ Corresponding author*
}

Received 8 September 2004. Accepted in revised form 28 February 2005

Key words: additives, cadmium, immobilisation, metal availability, plant uptake

\begin{abstract}

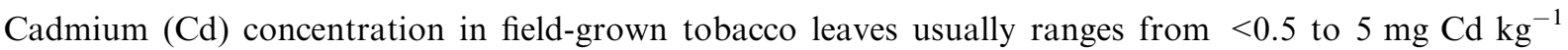
dry matter (DM). Reducing bioavailability of soil $\mathrm{Cd}$ by adding amendments to the soil could be suitable to mitigate $\mathrm{Cd}$ uptake by tobacco plants. However, little is known on the effect of inorganic amendments on agricultural soils with low $\mathrm{Cd}$ concentrations. Therefore, we performed a pot experiment with tobacco plants that were grown during 56 days in two neutral to alkaline agricultural soils with low total $\mathrm{Cd}$ concentrations (soil $1=0.4$, soil $2=0.7 \mathrm{mg} \mathrm{kg}^{-1}$ ). Both soils were amended or not with 1 or $5 \%$ of sepiolite, zeolite, hydroxyapatite and apatite $\mathrm{II}^{\mathrm{TM}}$. Major and trace elements were measured in mid-stalk position leaves. Soil metals were measured in a DTPA soil extraction to assess the effect of the amendments on metal bioavailability. Some amendments significantly reduced $\mathrm{Cd}$ concentration in tobacco leaves, but the effect differed between the two soils tested. In soil 1, the use of zeolite at the $1 \%$ dose was the most efficient, reducing the average $\mathrm{Cd}$ concentration from 0.6 to $0.4 \mathrm{mg} \mathrm{kg}^{-1}$. In soil 2 , the $5 \%$ hydroxyapatite treatment led to the maximal reduction in $\mathrm{Cd}$ concentration $(50 \%)$, with an average final $\mathrm{Cd}$ concentration in leaves of $0.7 \mathrm{mg} \mathrm{kg}^{-1}$ (control: $1.5 \mathrm{mg} \mathrm{kg}^{-1}$ ). There was a dose effect for some amendments in soil 2 (containing more $\mathrm{Cd}$ ), suggesting a reduced efficiency of the amendment at the lowest addition rate. DTPA extractable $\mathrm{Cd}$ and $\mathrm{Zn}$ measured at the end of the pot experiment were correlated to the metal concentrations in tobacco leaves suggesting that (1) the reduction in leaf $\mathrm{Cd}$ concentration was due to a reduction in metal availability to tobacco and (2) DTPA may be a suitable extractant to estimate $\mathrm{Cd}$ availability to tobacco plants in these two soils. In addition, a batch experiment was performed with the same soils to test a larger number of amendments, including the four tested in the pot experiment. Results were compared to those of the pot experiment to assess whether a batch experiment may predict the efficiency of an amendment on a given soil. It gave results compatible with those from the pot experiment except for the sepiolite and highlighted the broad range of potential amendments available for heavy metal remediation in crop plants.
\end{abstract}

\section{Introduction}

Cadmium (Cd) concentration in agricultural soils typically results either from contamination 
due to mining, smelting of metal ores, power stations, heating systems, waste incinerators, urban traffic, cement factories and application of phosphate fertilizers and sewage sludge (Alloway, 1995; di Toppi and Gabbrielli, 1999), or may have a geogenic origin (Alloway, 1995; Baize and Sterckeman, 2001; di Toppi and Gabbrielli, 1999; Dubois et al., 1998). Even when concentrations in soil are low, Cd may be readily taken up by plant roots and translocated into aerial organs where it can accumulate to fairly high levels, representing the main source of contamination for humans through the food chain and smoking (WHO, 1992; Wagner, 1993). Food-borne $\mathrm{Cd}$ is the major source of exposure for most people. In most areas not polluted with $\mathrm{Cd}$, average daily intakes from food are 10-40 $\mu \mathrm{g}$, but in polluted areas the value has been found to be several hundred $\mu \mathrm{g}$ per day. In non-polluted areas, uptake from heavy smoking may equal $\mathrm{Cd}$ intake from food (WHO, 1992).

Cadmium concentrations observed in plants are generally between 0.03 and $20 \mathrm{mg} \mathrm{kg}^{-1}$ and the critical range for phytotoxicity is usually $5-10 \mathrm{mg}$ $\mathrm{Cd} \mathrm{kg}^{-1}$ dry matter (DM) (Sauerbeck, 1989). The value set by several countries for consumption of leafy vegetables is $0.1 \mathrm{mg} \mathrm{Cd} \mathrm{kg}^{-1}$ fresh weight (Adriano, 2001). Tobacco (Nicotiana tabacum) can accumulate $\mathrm{Cd}$ at relatively high levels compared to other species (e.g. Mench et al., 1989; Wagner, 1993) and concentrations in field-grown tobacco leaves usually range from $<0.5$ to $5 \mathrm{mg} \mathrm{Cd} \mathrm{kg}{ }^{-1}$, although higher values can also be found (LugonMoulin et al., 2004).

Different actions can be undertaken in order to reduce the absorption of $\mathrm{Cd}$ by tobacco and other plants (Lugon-Moulin et al., 2004). Metal immobilisation by addition of specific amendments to the soil may represent a potentially rapid and rather inexpensive way to prevent excessive $\mathrm{Cd}$ uptake by tobacco plants. Amendments or ameliorants have long been used to improve the quality of agricultural soils (organic matter, lime). When dealing with mitigation of metal uptake however, most of the research has focused on remediation of highly heavy-metal contaminated soils in order to re-establish a vegetation cover and subsequently reduce wind and water erosion and contamination of the sur- roundings (e.g. Vangronsveld and Cunningham, 1998). Different materials, natural or synthetic, organic or inorganic, have been tested with success to reduce $\mathrm{Cd}$ availability to plants. These materials include phosphate $(\mathrm{P})$ compounds like rock phosphate (Basta et al., 2001), apatite, hydroxyapatite (Boisson et al., 1999; Chlopecka and Adriano, 1997; Knox et al., 2001, 2003), iron $(\mathrm{Fe})$ and manganese $(\mathrm{Mn})$ oxides and oxyhydroxides, and $\mathrm{Fe} / \mathrm{Mn}$-bearing amendments (Didier et al., 1993; Mench et al., 1994; McBride and Martinez, 2000; Sappin-Didier and Gomez, 1994; Sappin-Didier et al., 1997), organic amendments (Jamode et al., 2003; Walker et al., 2003, 2004), inorganic clay materials including micas (illites), vermiculites, 2:1 phyllosilicates modified or not, zeolites (Chlopecka and Adriano, 1997; Gworek, 1992; Knox et al., 2001), and sepiolite (AlvarezAyuso and Garcia-Sanchez, 2003). Various locally available industrial by-products may advantageously replace natural materials. They include beringite (Vangronsveld et al., 1996), red mud (Lombi et al., 2002, 2003), sterilized crushed bone meal (Hodson et al., 2000), red gypsum, phosphogypsum and dolomitic residue (Illera et al., 2004), and liming agents (although liming alone cannot be considered as a suitable longlasting treatment for metals stabilisation but rather as an enhancer of other amendment effects) (Knox et al., 2001; Tsadilas et al., 2005). Amendments may also be combined (Brown et al., 2003) and, with the exception of the organic amendments, they are usually applied at rates ranging from $0.5 \%$ to $5 \% \mathrm{DM}$.

In spite of successful results, some factors may limit the efficiency of these additives. Natural compounds are usually less expensive than synthetic ones, but their availability depends on the source. Moreover, their composition and purity and thus efficiency - may vary with their origin. Organic amendments are low cost adsorbents, readily available and relatively inexpensive, but their properties may vary from one batch to another, according to the sludge-processing (Merrington and Smernik, 2003; Richards et al., 2000) and, the nature of their inorganic fraction that is partly responsible for their immobilisation capacity (Brown et al., 1998). Their efficiency may also decrease with time through decomposition of the organic matter (McBride, 1995). Phosphate 
compounds affect not only heavy metal concentrations in plants, but also essential micronutrients: increasing addition of apatite to the soil has been found to decrease $\mathrm{P}, \mathrm{Mn}$ and Fe concentrations and induce elemental deficiency in plant tissues (Grant and Bailey, 1993), and enhance desorption of arsenic (As) in soil (Boisson et al., 1999) and, As, selenium ( $\mathrm{Se}$ ) and thorium (Th) in sediments (Kaplan and Knox, 2004). Excess of soil phosphate may pose an environmental concern in areas with surface waters sensitive to nutrient inputs. Application of Fe and Mn-rich compounds have resulted in contradictory results (Boisson et al., 1998; Hartley et al., 2004; McBride and Martinez, 2000; Sappin-Didier et al., 1997). There have been cases where liming agents were not efficient at reducing $\mathrm{Cd}$ uptake ( $\mathrm{Li}$ et al., 1996). In addition, lime must be periodically re-applied to keep soil $\mathrm{pH}$ at the desired level and the $\mathrm{pH}$ at which metal inactivation is best may be too high for optimal availability of essential nutrients. The reasons for these side effects are the nature of the amendments and the various mechanisms by which amendments alter the forms of metal contaminants in soil. These mechanisms are not fully understood and, depending on the soil and the amendment characteristics, may include precipitation, co-precipitation, surface complexation, humification, diffusion in micropores, sorption and redox transformations (e.g. Benedetti et al., 1996; Brümmer et al., 1988; Hiller and Brümmer, 1997; Kinniburgh et al., 1999; Koopal et al., 2001; Papadopoulos and Rowell, 1988; Randall et al., 1999; Skjemstad et al., 1998; Stipp et al., 1992; Spadini et al., 2003; Zachara et al., 1991).

In summary, an ideal amendment should be rapidly effective and long lasting, prevent leaching, and reduce metal bioavailability and plant uptake. In addition, it should be inexpensive, easy to handle and apply, safe for workers, compatible with and non-toxic to the plants, available and/or easy to produce, and not causing additional environmental impact to the site (Vangronsveld and Cunningham, 1998). If possible it should also offer benefits to the plants (e.g. supplying plant nutrients or increasing soil moisture holding capacity). So far, however, no real assessment of the various amendments effects, advantages and drawbacks has been performed and evaluation of the amendment efficiency relies on a site-to-site (or soil-to-soil) approach. In addition, the feasibility of the stabilisation technique on agricultural soils containing low $\mathrm{Cd}$ concentrations has not been sufficiently investigated (Sterrett et al., 1996).

The principal aim of this project was thus to test whether a variety of amendments were efficient at reducing $\mathrm{Cd}$ concentration in tobacco leaves of plants grown in low $\mathrm{Cd}$ contaminated agricultural soils without modifying the general nutrient status of the plants. Two complementary experiments - a pot experiment with tobacco plants and a batch experiment - were set up in controlled conditions. In the pot experiment, we tested four amendments on two soils with low $\mathrm{Cd}$ concentrations and measured concentrations of $\mathrm{Cd}$ and some essential elements in tobacco leaves. An assessment of available $\mathrm{Cd}$ in soil was obtained by a chemical soil extraction with diethylenetriaminepentaacetic acid (DTPA). In the batch experiment, we tested a larger number of amendments on these two soils and determined whether a batch experiment could help to predict the effect of amendments on DTPA-extractable $\mathrm{Cd}$ as measured in pots.

\section{Material and method}

\section{The soils}

Two soils were collected in Switzerland in the vicinity of Payerne (soil 1) and at Rafz (soil 2). Soil 1 is an agricultural soil regularly used for tobacco production. Soil 2 is an agricultural soil that was amended with municipal and industrial sewage sludge and, as a result, is contaminated with copper $(\mathrm{Cu})$, zinc $(\mathrm{Zn})$ and lead $(\mathrm{Pb})$ (Table 1). Both soils are neutral to slightly alkaline, the carbon content is in the range usually found for agricultural soils and the total $\mathrm{Cd}$ concentration measured by X-ray fluorescence (XRF) is low (Table 1). The soil characteristics are favourable to low metal availability to plants and DTPA-extractable $\mathrm{Cd}$, $\mathrm{Zn}, \mathrm{Cu}$ and $\mathrm{Pb}$ concentrations are all low. The results are compiled in Table 1 and more data on soil 2 can be found in Krebs et al. (1999) and Kayser (2000). 
Table 1. Selected characteristics of soil 1 (Payerne) and soil 2 (Rafz)

\begin{tabular}{lcc}
\hline & Soil 1 & Soil 2 \\
\hline pH & 7.7 & 6.8 \\
Org. C (\%) & 1.6 & 1.9 \\
Inorg. C (\%) & 1 & 0.2 \\
Clay (\%) & 18 & 15 \\
Slit $(\%)^{\mathrm{a}}$ & 39 & 31 \\
Sand $(\%)^{\mathrm{a}}$ & 43 & 54 \\
Total Cd $\left(\mathrm{mg} \mathrm{kg}^{-1}\right)$ & 0.4 & 0.7 \\
Total Cu $\left(\mathrm{mg} \mathrm{kg}^{-1}\right)$ & 27 & 54 \\
Total Zn $\left(\mathrm{mg} \mathrm{kg}^{-1}\right)$ & 62 & 505 \\
Total Pb (mg kg & \\
DTPA-extractable Cd $\left(\mu \mathrm{g} \mathrm{kg}^{-1}\right)$ & 20 & 362 \\
DTPA-extractable Cu $\left(\mathrm{mg} \mathrm{kg}^{-1}\right)$ & 57 & 167 \\
DTPA-extractable Zn $\left(\mathrm{mg} \mathrm{kg}^{-1}\right)$ & 1.9 & 6.5 \\
DTPA-extractable Pb $\left(\mu \mathrm{g} \mathrm{kg}^{-1}\right)$ & 0.8 & 31.8 \\
\end{tabular}

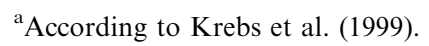

\section{The amendments}

Several amendments belonging to different categories were tested: (1) sepiolite $\left(\mathrm{Mg}_{4} \mathrm{Si}_{6} \mathrm{O}_{15}(\mathrm{OH}) 2 \cdot 6-\right.$ $\mathrm{H}_{2} \mathrm{O}$ ) is a magnesium silicate hydroxide hydrate mineral, commercialised as PANSIL-100 by TOLSA SA (Madrid, Spain), (2) a natural zeolite (Ø1-2.5 mm), purchased from Unipoint AG, Truttikon (CH), (3) a synthetic hydroxyapatite (calcium phosphate tribasic, $\left.\mathrm{Ca}_{10}(\mathrm{OH})_{2}\left(\mathrm{PO}_{4}\right)_{6}\right)$, purchased from Alfa Aesar (Karlsruhe, Germany), (4) apatite II ${ }^{\mathrm{TM}}$ (thereafter referred to as apatite II), a commercially available form of apatite derived from fish bones and purchased from Slater (UK) Ltd (United Kingdom), (5) a finely ground natural vermiculite (cation exchange capacity of 900-1000 mmol $\mathrm{kg}^{-1}$ ) purchased from Vermica AG (Bözen, CH), (6) an industrial compost (Brill ${ }^{\circledR}$ purchased from OBI, $\mathrm{CH}$ ) made of $96 \%$ peat, $4 \%$ Perlite, and containing traces of AGROSIL ${ }^{\circledR}$, guano, lime and nutrients, (7) a commercial charcoal from Swiss hardwood (Migros, $\mathrm{CH}$ ) ground in a ceramic mortar at $<100 \mu \mathrm{m}$ (this charcoal was found to fix large amounts of $\mathrm{Cd}$; Hammer et al., unpublished), (8) pure lime, a calcite $\left(\mathrm{CaCO}_{3}\right)$ that was obtained from Merck (No. 2064), (9) a cement flour, which is a mixture of pure calcium carbonate with marl, produced at the Eclepens cement industry (sample Q10111, collected the 2nd July 2003, Holcim, $\mathrm{CH}$ ) and ground and sampled before heating, (10) goethite $(\alpha-\mathrm{FeOOH})$ supplied by Ward's Natural Science Establishment Inc. (USA) as a row material and ground at $<100 \mu \mathrm{m}$ prior to use. These amendments were chosen either for their efficiency at reducing $\mathrm{Cd}$ or other metals uptake in (often) highly contaminated soils (hydroxyapatite, apatite, zeolite, goethite, vermiculite, compost, lime) or their potential efficiency at binding $\mathrm{Cd}$ (apatite II, sepiolite). They were also selected for their commercial availability (sepiolite, apatite II, zeolite, hydroxyapatite, cement flour, lime, compost). In some cases, pure materials were used (calcite, hydroxyapatite) to obtain maximum efficiency. In addition, because tobacco is produced worldwide, the amendments may need to be transported over large distances and thus low addition rates were preferred. Amendments that would have required large application rates like biosolids were not selected for the pot experiment.

Total element analysis was performed on finely ground samples (ceramic mortar Retsch RM 100) by XRF as for the soils and selected results are presented in Table 2. Cadmium concentrations are below detection limit except in goethite, sepiolite, lime, cement flour and hydroxyapatite. However, $\mathrm{Cd}$ is most likely included in the lattice of the components as impurity and thus not readily available for plants. In addition, the application at $5 \%$ addition rate of one amendment containing $1 \mathrm{mg} \mathrm{Cd} \mathrm{kg}{ }^{-1}$ would increase the soil total concentration of $0.05 \mathrm{mg} \mathrm{kg}^{-1}$.

\section{Protocol of the pot experiment}

\section{Experimental design}

The pot experiment was conducted on both soils with sepiolite, zeolite, hydroxyapatite and apatite II at 1 and $5 \%$ addition rates (calculated on a soil dry weight basis). Similar addition rates resulting in reduction of $\mathrm{Cd}$ concentration in plants have been commonly reported in the literature (Boisson et al, 1999; Chlopecka and Adriano, 1997; Gworek, 1992; Mench et al., 1994; Sappin-Didier and Gomez, 1994; Sterrett et al., 1996). Soils were passed through a $1-\mathrm{cm}$ sieve. Amendments were added and thoroughly mixed by hand. The pots were filled with $4 \mathrm{~kg}$ of soil 1 and $3.5 \mathrm{~kg}$ of soil 2 (difference due to different initial moisture content). All treatments were performed in triplicates. Three control pots per soil were also set up without amendment. Pots were watered and 


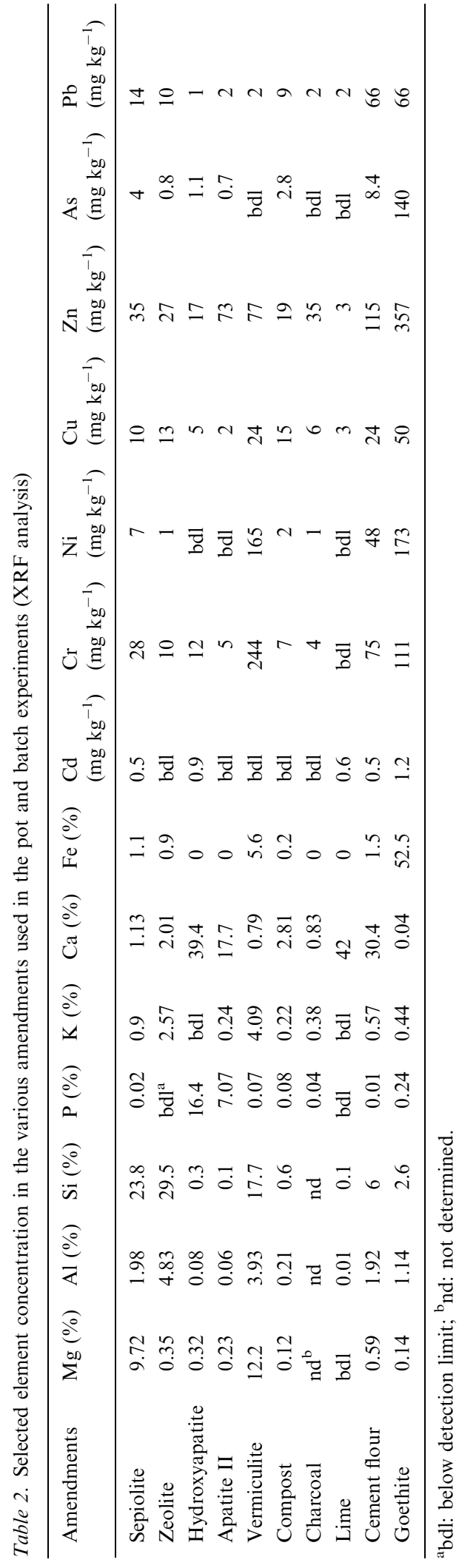

stored in a climate chamber, where they were left to settle a minimum of 6 weeks at room temperature before transplanting the tobacco plants.

\section{Plant cultivation and sampling}

We used the French variety ITB 33024 (Virginia), which resists black root rot (Chalara elegans), as the soils used for the pot experiment may have contained this pathogen. Seeds were sown in a metal-free substrate (peat or compost). The plants were watered regularly by overhead irrigation and fertilised once per week with WUXAL ${ }^{\circledR}$ Engrais Universel $\left(\mathrm{N} 100 \mathrm{~g} \mathrm{~L}^{-1}, \mathrm{P}_{2} \mathrm{O}_{5}\right.$ $100 \mathrm{~g} \mathrm{~L}^{-1}, \mathrm{~K}_{2} \mathrm{O} 75 \mathrm{~g} \mathrm{~L}^{-1}$, and $\mathrm{B}, \mathrm{Cu}, \mathrm{Fe}, \mathrm{Mn}$, $\mathrm{Mo}, \mathrm{Zn}$ ) at $0.2 \%$. The trays were set up in a climate chamber (day/night period $16 / 8$ hours, day/ night temperatures $20{ }^{\circ} \mathrm{C} / 18{ }^{\circ} \mathrm{C}, \quad 22^{\circ} \mathrm{C}$ after 4 weeks and $24{ }^{\circ} \mathrm{C}$ after two more weeks, light intensity of 500 lux).

When the plants had developed three pairs of leaves, they were transferred to the pots. They were then left to grow in the climate chamber during 56 days (day/night temperatures $24^{\circ} \mathrm{C} / 20^{\circ} \mathrm{C}$ ), with regular watering and random rotation of pots position. All the plants (except those growing in the soils with $5 \%$ apatite II) presented chlorosis symptoms on the lower leaves after about three weeks of growth in pots. They were then treated with a fertiliser once per week with a homemade nutrient solution (mixture of $1 \mathrm{~g} \mathrm{Ca}\left(\mathrm{NO}_{3}\right)_{2} \cdot 4 \mathrm{H}_{2} \mathrm{O}$, $0.25 \mathrm{~g} \mathrm{MgSO}_{4} \cdot 7 \mathrm{H}_{2} \mathrm{O}, 0.25 \mathrm{~g} \mathrm{KCl}, 0.25 \mathrm{~g} \mathrm{KH}_{2} \mathrm{PO}_{4}$ per litre) that alleviated the symptoms. Morphology and visual symptoms were recorded after 55 days of growth. After 56 days, all plants were harvested. Some of the plants had reached the flowering stage, others had not. As Cd accumulates less in the lower leaves than in the medium and upper ones (Lugon-Moulin et al., 2004), leaves were grouped by 4 (foliar stages), starting from the bottom of the plant. Only leaves from the second stage (hereafter referred to as mid-stalk position leaves) were analysed. The plant samples were oven-dried at $60{ }^{\circ} \mathrm{C}$ during one week and the total dry weight of the aerial parts was recorded.

\section{Soil sampling}

Soil samples representative of the rhizospheric soil (soil adhering to the roots after shaking of the root system) were taken from all pots after tobacco harvest. Practically, virtually no bulk soil was left. The samples were oven-dried at 
$40{ }^{\circ} \mathrm{C}$ until constant weight, sieved at $2 \mathrm{~mm}$ and extracted with DTPA (see below).

\section{Batch experiment}

All 10 amendments were tested in batch experiment in duplicates and at a single addition rate of $3 \%$. The 2 initial soils were oven-dried at $40{ }^{\circ} \mathrm{C}$ until a constant weight was reached, ground and sieved at $2 \mathrm{~mm}$. The finely ground amendments were added to the soil in $50 \mathrm{~mL}$ polyethylene (PE) flasks and humidified so that there was no water settling at the bottom of the flasks. They were let to oven-dry at $40{ }^{\circ} \mathrm{C}$ until dryness was reached ( 3 or 4 days). The samples were then re-moistened. The process was repeated during 1 month twice per week (eight repeated wet-and-dry cycles), in order to mimic an accelerated aging process. After the last drying, samples were extracted with DTPA (see below) in the same flasks in order to prevent soil loss and contamination.

\section{Analytical methods}

\section{Soil analysis}

Initial soil samples were dried at $40{ }^{\circ} \mathrm{C}$, and $2 \mathrm{~mm}$-sieved samples were analysed for $\mathrm{pH}$ (0.01 $\left.\mathrm{M} \mathrm{CaCl}_{2}\right)$ (FAL, 1998). Sub-samples were further ground to $100 \mu \mathrm{m}$ in a ceramic mortar (Restch RM 100, Germany) and analysed for organic and inorganic carbon and total elements by XRF (Spectro X-Lab2000 Kleve Germany).

DTPA-TEA extraction $(0.005 \mathrm{M}$ DTPA, $0.1 \mathrm{M}$ triethanolamine and $0.01 \mathrm{M} \mathrm{CaCl}_{2}$ at $\mathrm{pH}$ 7.3; soil/solution $1 / 2$; horizontal shaker $120 \mathrm{~min}$, centrifugation and filtration on Schleicher \& Schuell $0.45 \mu \mathrm{m}$ membrane; Schleicher \& Schuell, Dassel, Germany), as proposed by Lindsay and Norvell (1978), was performed on $2 \mathrm{~mm}$-sieved samples to assess the metal DTPA-extractable fraction in the initial soils and both in the pot experiment after harvest of the tobacco plants and in the batch experiment after the wet-anddry cycles. The DTPA extraction was chosen after preliminary comparative tests including DTPA, EDTA (ethylenediaminetetraacetic acid)$\mathrm{NH}_{4} \mathrm{OAc}$ at $\mathrm{pH} 4.65,1 \mathrm{M} \mathrm{NH}_{4} \mathrm{NO}_{3}$ and $1 \mathrm{M}$ $\mathrm{NH}_{4} \mathrm{OAc}$. DTPA was found to be the most suitable owing to the soil $\mathrm{pHs}$ and because $\mathrm{Cd}$ concentrations in the two latter extractants were below the detection limit and did not discriminate between the soils.

"Initial soil" always refers to soil samples analysed before any experiment. "Control soil" refers to soil samples collected at the end of the pot experiment, in pots grown with tobacco and without amendment. "Treated soil" is similar to "control soil" but with amendment.

\section{Plant analysis}

Finely ground plant samples $(0.5 \mathrm{~g})$ were digested in $8 \mathrm{~mL} \mathrm{HNO}_{3} 65 \%$ (Fluka, Buchs, Switzerland) and evaporated. The residues were re-dissolved in $1 \mathrm{~mL} \mathrm{HClO}_{4} 70 \%$ (Fluka, Buchs, Switzerland) and heated $1 \mathrm{~h}$ to $235^{\circ} \mathrm{C}$ before dilution to $10 \mathrm{~mL}$ with purified water (modified from Keller et al., 2003).

\section{Elemental analyses}

Cadmium and the other elements were measured in soil extracts and plant digests by Inductively Coupled Plasma-Atomic Emission Spectrophotometry (ICP-AES) (Plasma 2000; Perkin Elmer, Wellesley, USA). All extractions and digestions were performed using p.a. or suprapur products as required. Deionised water (MilliQ) was used throughout the various extractions. All plant and soil samples were run together with certified reference material (sample W921, Wageningen, NL) for soil or in-house standard for plant to assess the accuracy of the measurements.

\section{Statistical analysis}

Analyses of variance (ANOVA) were performed to test the soil, the amendment and the dose effects on element concentrations in plants as well as on biomass production (ANOVA, SYSTAT 10.2, SYSTAT Software Inc.). The effect of a given factor was considered significant when the $P$-value was $<0.05$. In addition Student's $t$-tests were performed to test whether the average concentrations in leaves of tobacco grown in the treated pots differed from those of tobacco grown in the control pots. The difference between means was significant (labelled * in the figures) when $P<0.05$. Pearson's correlation coefficients were calculated between element concentrations measured in plants and in DTPA extracts (pot experiment), either combining the two soil datasets or for each soil independently. 
The significance was: $* * *$ for $2 \alpha<0.001, * *$ for $2 \alpha<0.01$ and, $*$ for $2 \alpha<0.05$.

\section{Results}

\section{The pot experiment}

\section{Biomass production}

The overall chlorosis that developed on all plants after about 3 weeks of growth in pots (except on plants growing on $5 \%$ apatite II) was probably due to a nutrient depletion. It was remediated by the addition of fertiliser. Plantlets transplanted to pots with $5 \%$ apatite II were not able to establish. Most of them immediately died and had to be replaced several times. The growth of the plantlets that ultimately established was highly variable (large $\mathrm{SD}$ ). For this treatment the growth period was shorter (all plants were harvested at the same time) and resulted in an under-estimated biomass production at harvest.

The type of soil as well as the treatment had an influence on biomass production (ANOVA, soil effect: $F=53.4, \quad P<0.001$; amendment effect: $F=13.8, P<0.001$ ), but there was no significant soil $\times$ amendment interaction $(F=1.06, P=0.41)$. Control plants on soil 2 produced about twice as much biomass as those on soil 1 , whereas plants in the treated soil 2 produced on average $50 \%$ more biomass than those in the treated soil 1 (Figure 1). Plants grown on $1 \%$ apatite II were the exception, with a similar biomass on both soils.

There were no significant differences between the 1 and $5 \%$ treatments, except for apatite II (see below). In soil 2 the difference between 1 and $5 \%$ sepiolite was only marginally significant $(P=0.066)$. The biomass in the $5 \%$ apatite II treatment was halved in soil 2 and divided by four in soil 1 when compared to the $1 \%$ dose. This large difference was probably due to the difficulty for plants to establish and is not thus directly comparable to the other treatments, but it shows that $5 \%$ apatite clearly impacted plant growth. In addition, the morphology of tobacco plants growing in pots with apatite II (both treatments) was different from that of the other plants, with larger leaves, no chlorosis symptoms and thicker stems.

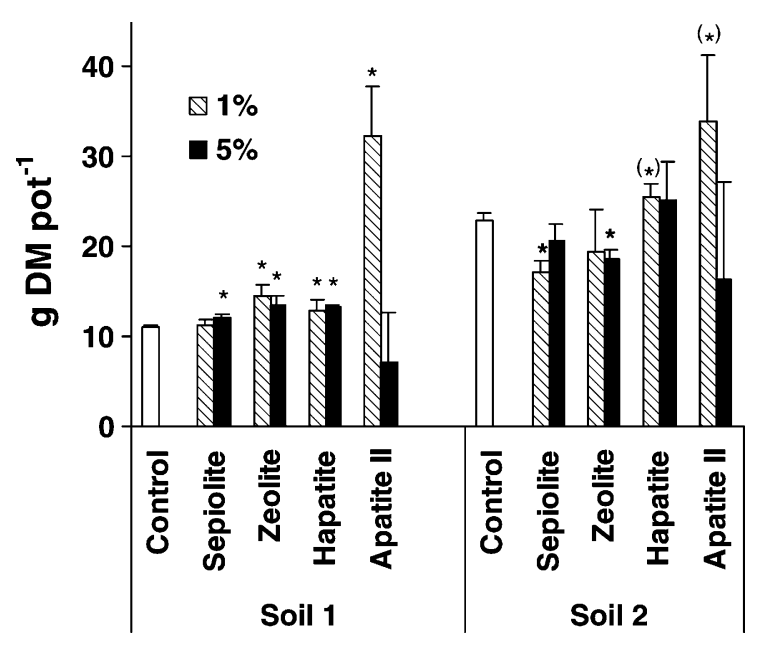

Figure 1. Dry shoot biomass produced by tobacco plants grown 56 days in pots, according to the soil and the amendment; *means significance of Student's $t$-test at $P<0.05$ and $\left({ }^{*}\right)$ at $P<0.1$.

\section{Effect of treatments on nutrient concentrations in plants}

Figures 2 and 3 give the results of elemental concentrations in plants for some major and trace elements. The soil type as well as the amendments had a significant effect on $\mathrm{P}$, magnesium $(\mathrm{Mg})$ and calcium $(\mathrm{Ca})$ concentrations in tobacco leaves (two-way ANOVA, all $P<0.001$ ), but not on $\mathrm{Fe}$ concentrations. However, the effect of amendments on $\mathrm{P}$ was no longer significant when apatite II was excluded from the calculations. The soil $\times$ treatment interaction was significant neither for $\mathrm{Mg}, \mathrm{Ca}$ and $\mathrm{Fe}$, nor for $\mathrm{P}$ when the apatite II treatment was removed from the analyses. In both soils, $\mathrm{Ca}$ concentrations were reduced in tobacco grown in the sepiolite and zeolite treated pots when compared with the control pots, but a significant increase was observed in the pots treated with apatite II. The effects of the different treatments on $\mathrm{Mg}$ and $\mathrm{P}$ concentrations differed between the 2 soils and according to the amendment and could either lead to an increase or a decrease of $\mathrm{Mg}$ and $\mathrm{P}$ concentrations.

\section{Effect of treatments on $\mathrm{Cd}$ and other metals concentrations in plants}

There was a significant soil effect on the concentrations of $\mathrm{Cd}, \mathrm{Zn}$ and $\mathrm{Pb}$ (ANOVA, all $P<0.001)$. For each of them, as well as for $\mathrm{Cu}$, there was also an amendment effect (ANOVA, $P<0.001$ for $\mathrm{Cd}, P=0.043$ for $\mathrm{Zn}, P=0.015$ 
76
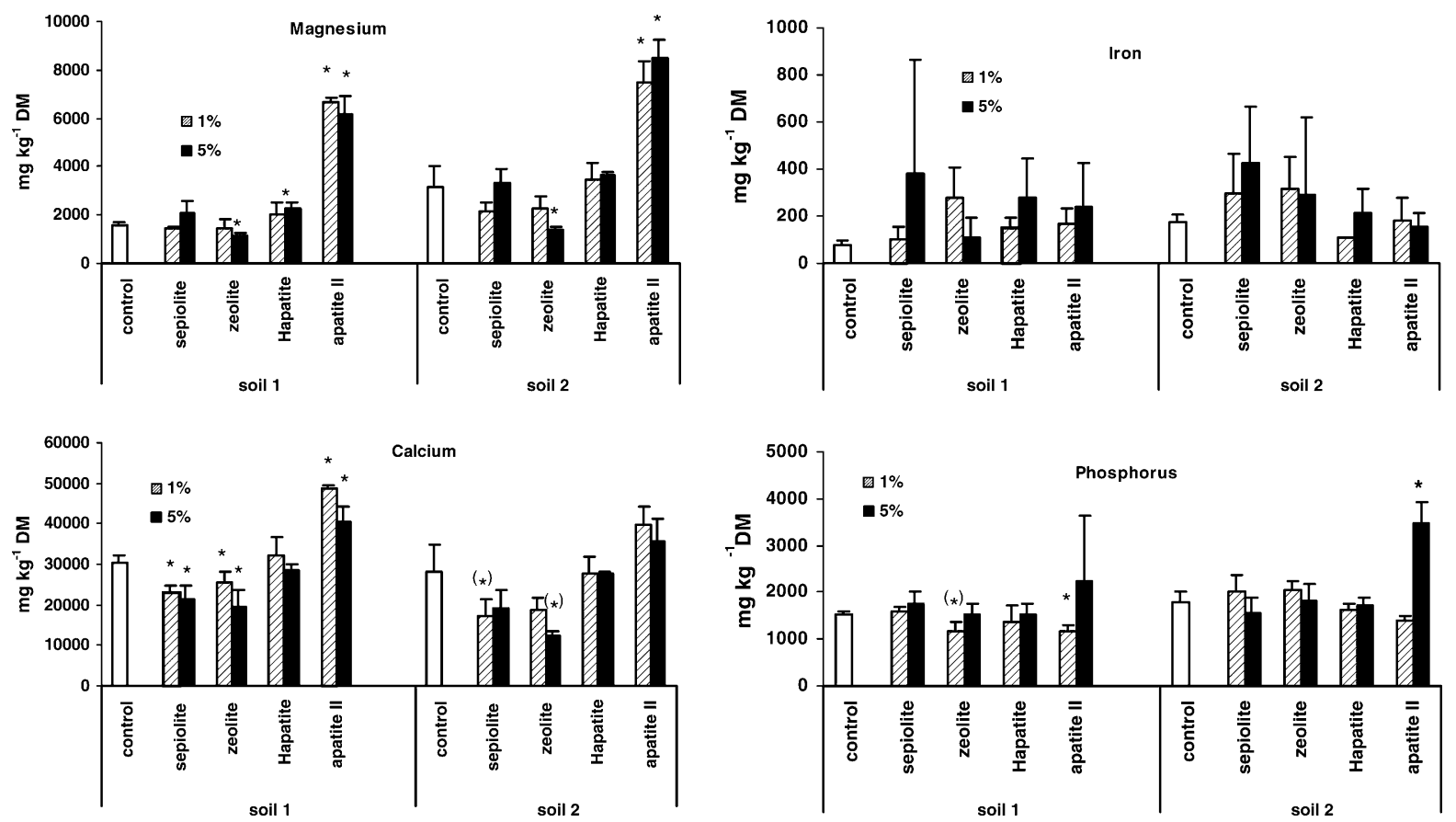

Figure 2. Magnesium, $\mathrm{Ca}, \mathrm{Fe}$ and $\mathrm{P}$ concentrations in the mid-stalk position leaves of tobacco grown in soil 1 (Payerne) and soil 2 (Rafz) with and without amendments; *means significance of Student's $t$-test at $P<0.05$ and $\left({ }^{*}\right)$ at $P<0.1$; Hapatite $=$ hydroxyapatite.
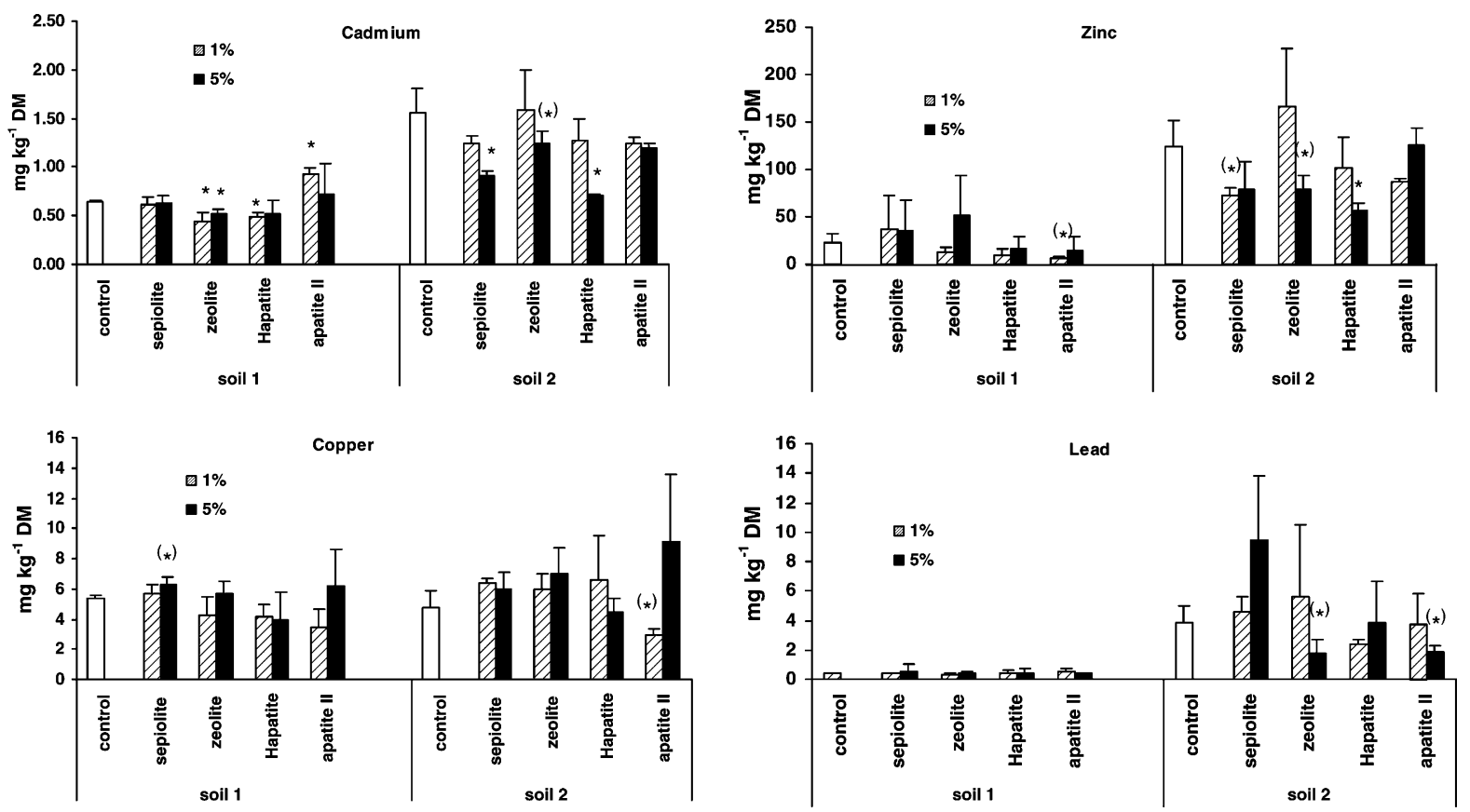

Figure 3. Cadmium, $\mathrm{Zn}, \mathrm{Cu}$ and $\mathrm{Pb}$ concentrations in the mid-stalk position leaves of tobacco grown in soil 1 (Payerne) and soil 2 (Rafz) with and without amendments; *means significance of Student's $t$-test at $P<0.05$ and $\left({ }^{*}\right)$ at $P<0.1$; Hapatite $=$ hydroxyapatite. 
for $\mathrm{Cu}$ and, $P=0.036$ for $\mathrm{Pb}$ ). However, for $\mathrm{Cu}$ and $\mathrm{Pb}$ it could either lead to an increase $(5 \%$ sepiolite in soil 1 and $1 \%$ zeolite in soil 2) or a decrease $(1 \%$ apatite in soil 2$)$ in concentration.

Cadmium concentrations were higher in tobacco grown on the sewage sludge-contaminated soil (soil 2) than in plants grown on the uncontaminated soil 1 . A significant decrease in Cd concentration was observed with both addition of zeolite $(t$-test, $P=0.020$ for $1 \%$ and $P=0.028$ for $5 \%)$ and $1 \%$ hydroxyapatite $(P=0.016)$ in soil 1 and, with $5 \%$ sepiolite ( $t$-test, $P=0.046$ ) and $5 \%$ hydroxyapatite $(P=0.030)$ in soil 2 . In this soil, $5 \%$ zeolite gave a marginal decrease in Cd concentration $(P=0.123)$. The large standard deviation measured in the control pots was probably responsible for the non-significance of $\mathrm{Cd}$ concentration reduction in other treatments. There was also a significant interaction between soils and amendments (ANOVA, $F=6.86$, $P<0.001)$. The largest reduction in $\mathrm{Cd}$ concentration amounted to $33 \%$ in soil 1 (1\% zeolite) and $50 \%$ in soil 2 (5\% hydroxyapatite). There was a significant dose effect in soil 2 (ANOVA, $F=25.2, P<0.001$ ), but not in soil 1 . In soil 2 , a $5 \%$ addition was necessary to reduce significantly $\mathrm{Cd}$ concentrations in plants.

Cadmium and $\mathrm{Zn}$ concentrations in plant leaves were positively correlated when data for the two soils were combined (Figure 4: $r=0.745^{* * *}$ ) and in soil 2 alone as well $\left(r=0.667^{* * *}\right.$, Table 3). In soil 2, as for $\mathrm{Cd}, 5 \%$ hydroxyapatite was efficient at reducing $\mathrm{Zn}$ concentrations in

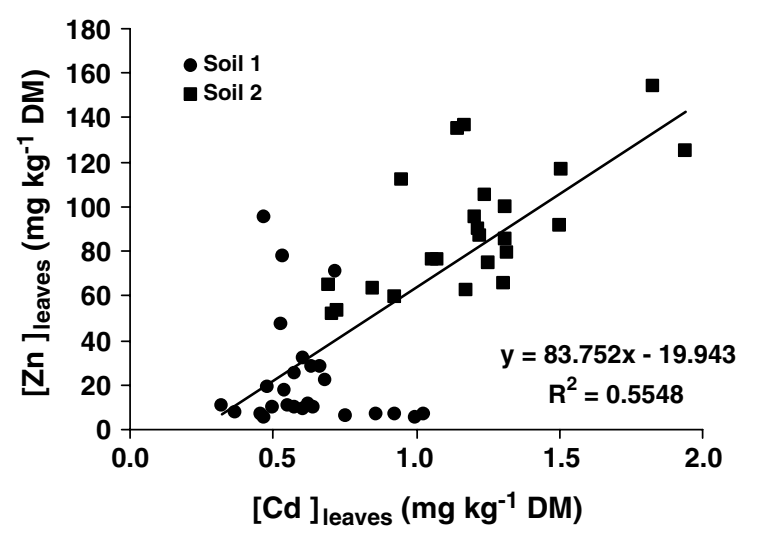

Figure 4. Linear regressions between $\mathrm{Cd}$ and $\mathrm{Zn}$ concentrations in the mid-stalk position tobacco leaves.
Table 3. Pearson's correlations between Cd concentration in mild-stalk position leaves and selected element concentrations in leaves and soils (amendment-treated and control pots)

\begin{tabular}{lllll}
\hline & Soil 1 & & Soil 2 & \\
\hline $\mathrm{Cu}$ in tobacco & 0.152 & - & 0.052 & - \\
$\mathrm{Fe}$ in tobacco & 0.062 & - & 0.06 & - \\
$\mathrm{Mg}$ in tobacco & 0.756 & $* * *$ & 0.014 & - \\
$\mathrm{Mn}$ in tobacco & 0.531 & $*$ & 0.05 & - \\
$\mathrm{Ni}$ in tobacco & 0.263 & - & 0.309 & - \\
$\mathrm{Pb}$ in tobacco & 0.125 & - & 0.045 & - \\
$\mathrm{Zn}$ in tobacco & 0.125 & - & 0.667 & $* * *$ \\
$\mathrm{P}$ in tobacco & & - & 0.066 & - \\
DTPA-extractable Cd & 0.278 & - & 0.299 & - \\
DTPA-extractable $\mathrm{Zn}$ & 0.405 & - & 0.467 & $*$ \\
\hline
\end{tabular}

$* * * 2 \alpha<0.001 . * 2 \alpha<0.05$.

leaves ( $t$-test, $P=0.045)$ whereas $1 \%$ sepiolite and $5 \%$ zeolite induced a marginally significant $\mathrm{Zn}$ reduction (respectively $P=0.073$ and $P=0.088$ ). In soil 1 , all $\mathrm{Zn}$ concentrations, including those of the control pots, were low and close to $25 \mathrm{mg} \mathrm{kg}^{-1}$ that is set as the limit for $\mathrm{Zn}$ deficiency for tobacco. And although a trend could be detected, there was no significant difference in $\mathrm{Zn}$ concentrations between the control and treated pots, except a marginally significant reduction obtained with $1 \%$ apatite II ( $t$-test, $P=0.059)$. Therefore, in the two soils tested, some of the amendments chosen for their potential ability to reduce $\mathrm{Cd}$ uptake appeared to be also efficient at reducing $\mathrm{Zn}$ uptake.

Amendments had no significant effect on $\mathrm{Cu}$ and $\mathrm{Pb}$ concentrations in tobacco leaves, except marginally $5 \%$ sepiolite for $\mathrm{Cu}$ (increase, $t$-test, $P=0.059)$ in soil 1 and, in soil $2,5 \%$ zeolite $(P=0.069), 5 \%$ apatite II $(P=0.073)$ for $\mathrm{Pb}$ and $1 \%$ apatite II $(P=0.093)$ for $\mathrm{Cu}$.

\section{Effect of treatments on element concentrations in DTPA extracts}

Figure 5 presents the results of the DTPA extractions performed on the rhizospheric soil collected from the pots after tobacco cultivation. Cadmium concentration in soil 1 was very low (about $20 \mu \mathrm{g} \mathrm{kg}^{-1}$ ). Therefore, the results of DTPA extractions for soil 1 should be taken with caution. A significant decrease in soil DTPA-extractable Cd was measured with $5 \%$ sepiolite ( $t$-test, $P=0.026)$ and $5 \%$ hydroxyapatite $(t$-test, $P=0.001)$ in soil 2 , and with $5 \%$ 

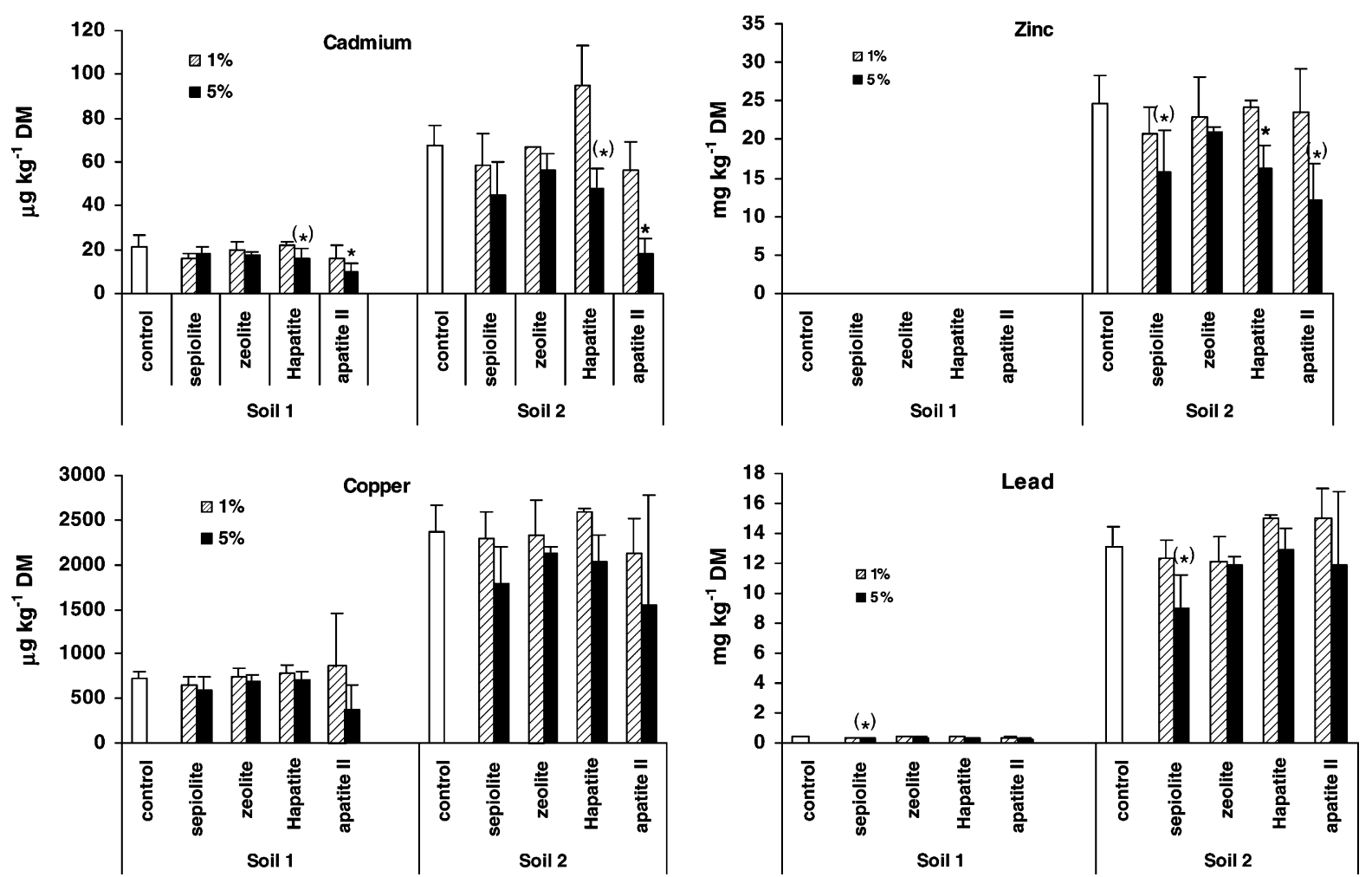

Figure 5. Concentrations of DTPA-extractable $\mathrm{Cd}, \mathrm{Zn}, \mathrm{Cu}$ and $\mathrm{Pb}$ performed on soils from the pot experiment after tobacco harvest; *means significance of the $t$-test at $P<0.05$ and $(*)$ at $P<0.1$; Hapatite $=$ hydroxyapatite.

apatite II in both soils (only 2 samples in soil 1 and $P=0.039$ for soil 2 ). In soil 2 , zeolite tended to decrease the amount of DTPA-extractable $\mathrm{Cd}$, though not significantly.

As for Cd in soil 2, DTPA-extractable Zn concentrations could be significantly decreased by the addition of $5 \%$ hydroxyapatite $(P=0.040)$, whereas 5\% sepiolite $(P=0.089)$ and $5 \%$ apatite II $(P=0.097)$ could decrease only marginally DTPA-extractable $\mathrm{Zn}$ (Figure 5; in soil 1, Zn concentrations were below detection limit). The DTPA-extractable $\mathrm{Cu}$ and $\mathrm{Pb}$ concentrations did not significantly differ between the amendmenttreated and control pots, except $\mathrm{Pb}$ concentrations with 5\% sepiolite (marginally) in both soils (Figure 5).

\section{Relation between DTPA-extractable Cd and Cd uptake by plants}

Although DTPA-extractable $\mathrm{Cd}$ and $\mathrm{Cd}$ concentrations in leaves were significantly correlated $\left(r=0.744^{* * *}\right)$ when the two soils data were pooled, there was no correlation for each soil taken individually (Table 3 ). In soil 2 , Cd concentration in leaves was also significantly correlated with DTPA-extractable $\mathrm{Zn}\left(r=0.467^{*}\right.$, Table 3$)$.

\section{The batch experiment}

Figure 7 shows the amount of DTPA-extracted $\mathrm{Cd}$ in soil 1 and 2 after 8 wet/dry cycles, for each soil/amendment mixture. When compared with the DTPA-extractable $\mathrm{Cd}$ concentrations measured in the initial soils (resp. 57 and $167 \mu \mathrm{g} \mathrm{kg}^{-1}$ for soil 1 and soil 2, Table 1), all treatments except the sepiolite reduced DTPAextractable $\mathrm{Cd}$. The use of lime resulted in the lowest average DTPA-extractable $\mathrm{Cd}$ in soil 1, but average DTPA-extractable $\mathrm{Cd}$ concentrations were always very low in soil 1 . In soil 2 , vermiculite seemed the most effective amendment. Similar results were obtained for $\mathrm{Zn}$ and $\mathrm{Cu}$ (data not shown). 

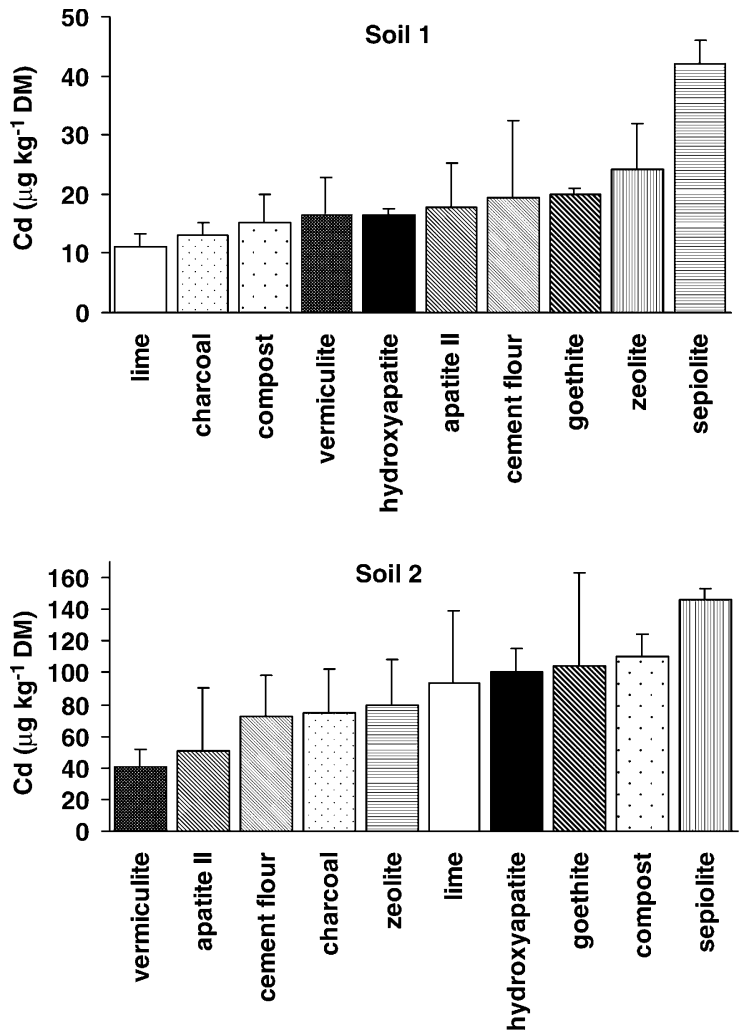

Figure 6. DTPA-extractable Cd concentrations measured in soil 1 and soil 2 after 8 dry/wet cycles in the batch experiment.

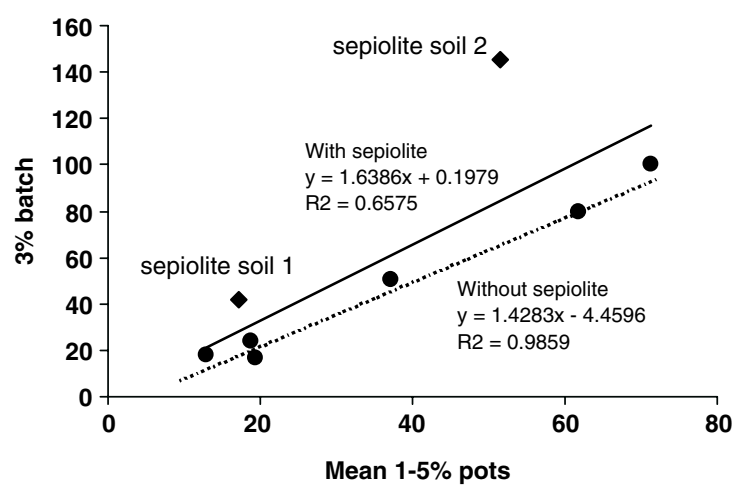

Figure 7. Relationship between average DTPA-extractable Cd concentrations measured in pot and batch soils. Solid line $=$ linear regression with all points and dashed line $=$ linear regression without the sepiolite points.

\section{Relation between the batch and pot experiment results}

Figure 7 shows the correlation between the results of the pot experiment (by taking the mean of the $1 \%$ and $5 \%$ dose results) and the batch experiment ( $3 \%$ dose) for the DTPA-extracted $\mathrm{Cd}$ for soil 1 and 2, and the four amendments common to both experiments. The amount of $\mathrm{Cd}$ extracted from the batch samples and the amount of $\mathrm{Cd}$ extracted from pot soil samples were significantly correlated (Pearson's correlation coefficient $r=0.813^{*}$ ). The sepiolite treatment resulted in the highest DTPA-extractable $\mathrm{Cd}$ concentrations in the batch experiment (Figure 6). We performed a regression analysis without this amendment and the regression was improved $(r=0.993 * *)$. This result suggests that for all soil/amendments combinations except those involving sepiolite, the 8 wet/dry cycles of the batch experiment gave the same order of efficiency of the different amendments than 3-6 weeks of equilibration and 6 weeks with tobacco growing in the pots when DTPA-extractable $\mathrm{Cd}$ concentrations were compared. However, the amount of $\mathrm{Cd}$ extracted from the batch samples was always larger than the fraction extracted from the pot samples.

\section{Discussion and conclusion}

The pot experiment gave information on element uptake by plants according to the soil and the treatment (type and rate). It also allowed assessing the change in DTPA-extractable metal after harvest of tobacco grown with and without treatment.

We showed that several amendments could significantly decrease $\mathrm{Cd}$ concentration in tobacco leaves grown on agricultural soils with low $\mathrm{Cd}$ concentrations. The $\mathrm{Cd}$ concentrations we reported in tobacco leaves lie within the range commonly reported in field-grown tobacco (Lugon-Moulin et al., 2004). So far there has been no direct correlation made between $\mathrm{Cd}$ concentration in tobacco leaves and Cd intake by smokers. However, it is hypothesised that a reduced $\mathrm{Cd}$ content would decrease $\mathrm{Cd}$ in smoke. The effects of the amendments on leaf $\mathrm{Cd}$ concentrations were however soil- and dose-dependent. The significant interaction between soils and amendments underlines the necessity to choose the amendment according to the soil type.

Some amendments had also an effect on other element concentrations in plants. Zinc concentrations measured in tobacco grown in soil 1 were 
lower than in the control pots and may have led to a $\mathrm{Zn}$ deficiency (below 20-25 $\mathrm{mg} \mathrm{Zn} \mathrm{kg} \mathrm{kg}^{-1}$ DW). However, $\mathrm{Zn}$ concentrations in control plants were already very low and no visible deficiency symptoms were specifically observed on the treated tobacco plants. In addition, no morphological difference was observed between tobacco plants grown on soils 1 and 2 when treated with the same amendment. The most significant changes were observed for $\mathrm{Ca}$ and $\mathrm{P}$ concentrations in tobacco plants grown in pots treated with apatite II. This may have resulted from the release of $\mathrm{Ca}$ and $\mathrm{P}$ contained in apatite II as well as from the different growth behaviour observed with both addition rates of this treatment compared to the other treatments.

The addition of amendments also decreased DTPA-extractable Cd, although not always significantly. The mechanisms involved in the reduction of DTPA-extractable $\mathrm{Cd}$ may be various and depend on both the amendments and the soil characteristics, which play an essential role in metal availability. Assessment of the changes in the $\mathrm{Cd}$ forms and measurement of a larger set of soil parameters would allow more insight into the mechanisms that might be responsible for $\mathrm{Cd}$ immobilisation.

One of the objectives of the pot experiment was also to investigate the relationship between the DTPA-extractable $\mathrm{Cd}$ in soils and the concentration of $\mathrm{Cd}$ found in tobacco growing on these soils. Practically, this could lead to an estimate of the expected concentration of $\mathrm{Cd}$ in crops prior to their cultivation, applying a simple technique (chemical extraction), if DTPA was able to assess correctly $\mathrm{Cd}$ availability to tobacco. Indeed, $\mathrm{Cd}$ concentrations in tobacco leaves were correlated to DTPA-extractable Cd in soil 2, or when both soil datasets were pooled. However, measurements in soil have been performed after plant harvest and hence, integrated both the amendment effect and the fraction of $\mathrm{Cd}$ taken up by the plant. As the total Cd incorporated into the plant amounted to only $10 \%$ of the sum DTPA-extractable $\mathrm{Cd}+\mathrm{Cd}$ in plants in soil 1 and $13 \%$ in soil 2 , it is likely that the reduction in $\mathrm{Cd}$ concentrations in tobacco leaves was directly related to the decrease in DTPAextractable $\mathrm{Cd}$ in soil. Tsadilas et al. (2005) also observed a parallel decrease of DTPA-extractable
$\mathrm{Cd}$ and $\mathrm{Cd}$ concentration in Virginia tobacco leaves grown in the field after treatment of the soil with $3000 \mathrm{~kg} \mathrm{Ca}(\mathrm{OH})_{2} \mathrm{ha}^{-1}$. It also suggests that DTPA-extractable Cd may represent a soil $\mathrm{Cd}$ fraction available to tobacco plant in the soils we investigated. Similar results were obtained for Zn. However, published studies aiming at predicting $\mathrm{Cd}$ concentrations in tobacco leaves using various soil properties and $\mathrm{Cd}$ chemically extractable fractions suggest that the use of a single extractant like DTPA may not accurately predict Cd uptake by tobacco in all field situations (e.g. Adamu et al., 1989; Miner et al., 1997; Tsadilas, 2000) and that soil characteristics such as $\mathrm{pH}$, cation exchange capacity and clay content should be included (Wang et al., 2004). This aspect has not been tested in our experiment and ought to be further developed and tested for tobacco in low $\mathrm{Cd}$ contaminated soils, using larger soil datasets.

Chlopecka and Adriano (1997) tested 1.5\% zeolite and $0.4 \%$ apatite on a soil artificially contaminated with increasing concentrations of $\mathrm{Cd}$. They found that the two amendments were efficient at reducing $\mathrm{Cd}$ concentrations in 3-weekold maize and in barley. Cadmium concentration in plants having initially $0.65 \mathrm{mg} \mathrm{Cd} \mathrm{kg}$ could be reduced by $64 \%$ with $0.4 \%$ apatite. They obtained similar results for $\mathrm{Zn}$. Our results are in the same order of magnitude, although lower for $\mathrm{Cd}$ (respectively $33 \%$ and $40 \% \mathrm{Cd}$ and $\mathrm{Zn}$ reduction for soil 1 with $1 \%$ zeolite and no effect on soil 2, and, respectively, $25 \%$ and $55 \% \mathrm{Cd}$ and $\mathrm{Zn}$ reduction for soil 1 and $18 \%$ and $18 \%$ for soil 2 with $1 \%$ hydroxyapatite). In addition, they found that the amendments were more efficient when $\mathrm{Cd}$ concentrations in soil were low, probably because at higher soil $\mathrm{Cd}$ concentrations the amount of amendment added was not sufficient to immobilise all available $\mathrm{Cd}$. In our case, the limited decrease in $\mathrm{Cd}$ concentration in plants grown on the uncontaminated soil 1 with the $1 \%$ and $5 \%$ treatment suggests that we were dealing with residual $\mathrm{Cd}$ concentrations in soil. As a result, the addition of $1 \%$ amendment to this soil was enough to reduce metal availability to plants. In soil 2 however, reduction in $\mathrm{Cd}$ concentration was larger when the $5 \%$ dose was applied irrespective of the treatment, suggesting that a $1 \%$ addition rate was not enough to 
immobilise all available Cd. Larger doses may be even more efficient but not realistic. The technical feasibility will have to be assessed. The difference between our results and those of Chlopecka and Adriano (1997) may further be due to the fact that tobacco is more efficient at taking up $\mathrm{Cd}$ and translocating it to its leaves than maize (Mench et al., 1989; Mench and Martin, 1991). For example, Mench et al. (1994) and Sappin-Didier and Gomez (1994) found that $\mathrm{Cd}$ concentrations in plant shoots were always lower and the percent of reduction larger for ryegrass than for tobacco. Larger reduction in $\mathrm{Cd}$ uptake by plants using synthetic zeolite or phosphate compounds was usually obtained in highly contaminated soils (Boisson et al., 1999; Gworek, 1992), although Basta et al. (2001) did not find any beneficial effect of rock phosphate on $\mathrm{Cd}$ uptake by lettuce grown on highly contaminated soils.

Studies on Cd removal from waste water by sepiolite (Brigatti et al., 1998) and batch and columns studies performed on a contaminated soil (Alvarez-Ayuso and Garcia-Sanchez, 2003) have given promising results for $\mathrm{Cd}$ and $\mathrm{Zn}$ removal. However, no experiment had been performed to test its effect on metal uptake by plant. In our experiment, sepiolite was efficient at reducing both $\mathrm{Cd}$ and $\mathrm{Zn}$ concentrations in tobacco grown in soil 2. Its use would deserve further experimentation. Previous results obtained with apatite II $^{\mathrm{TM}}$ have proved its efficiency at reducing $\mathrm{Cd}$ concentrations in the soil solution (Matheson et al., 2002). In our experiment, the $5 \%$ treatment induced plantlets mortality, but then produced healthier plants once successfully transplanted. Because of these ambiguous results, it is difficult to meaningfully compare these results with those of the other amendments, and further experimentation is needed before concluding on the suitability of apatite II $^{\mathrm{TM}}$ for use with tobacco plants.

Because tobacco seems to be able to take up $\mathrm{Cd}$ efficiently, $\mathrm{Cd}$ concentrations in leaves can reach relatively high levels even in soil with relatively low $\mathrm{Cd}$ concentrations. Experiments with tobacco are scarce and have been performed on highly contaminated soils. They have shown that amendments such as steel shot (Sappin-Didier and Gomez, 1994) or hydrous manganese oxides (HMO) (Mench et al., 1994) can significantly reduce $\mathrm{Cd}$ concentrations in tobacco leaves (cv. PBD6). Mench et al. (1994) reported $41 \%$ and $63 \%$ reduction with $1 \% \mathrm{HMO}$ in two different soils. Sappin-Didier and Gomez (1994) reported $16 \%$ and $40 \%$ reduction with $1 \%$ steel shot in the two soils they investigated. The differences with our results may be due to factors like the different amendments and soils used, and differences in DTPA-extractable Cd in soil. As already mentioned, DTPA-extractable Cd concentrations in our 2 soils were low, and control tobacco leaves contained 0.6 and $1.5 \mathrm{mg} \mathrm{Cd} \mathrm{kg}{ }^{-1}$. In the studies of Mench et al. (1994) and Sappin-Didier and Gomez (1994), control tobaccos contained ca. 40 and $120 \mathrm{mg} \mathrm{Cd} \mathrm{kg}^{-1}$, depending on the soil. It has also been reported that $\mathrm{Cd}$ uptake and subsequent tissue partitioning in tobacco may vary with $\mathrm{Cd}$ exposure, and different varieties may respond differently (Lugon-Moulin et al., 2004). This should also be kept in mind when comparing results across studies.

The aim of the batch experiment was (1) to test a larger number of amendments in soil 1 and 2 for the reduction of DTPA-extractable $\mathrm{Cd}$ and, (2) to assess the ability of a batch experiment to predict the effect of an amendment on $\mathrm{Cd}$ uptake by plants by comparing the results with those of the pot experiment. The batch and pot experiments gave similar results for each amendment, except for sepiolite in soil 2. In the pot experiment, the reduction in DTPA-extractable $\mathrm{Cd}$ concentration was between $0 \%$ and $45 \%$ when compared to control pots (with tobacco), but reached $57-78 \%$ when compared to the initial soil data. In the batch experiment, the reduction was between $40 \%$ and $70 \%$ (except sepiolite which gave a, respectively, $26 \%$ and $13 \%$ reduction for soil 1 and 2) when compared to the DTPA-extractable concentrations in the initial soils. The difference observed between the two experiments when final DTPA-extractable concentrations were compared (Figure 7) may be due both to a difference in the length and protocol of "aging" of the soil/amendment mixture and plant uptake that also contributed to the decrease of the amount of DTPA-extractable $\mathrm{Cd}$ in the pot experiment. However, in spite of a high correlation between the pot and the batch experiments, it is not possible yet to 
use the results of the batch experiment to choose with accuracy the best amendment for a given soil. This correlation will have to be confirmed and refined using a larger soil and amendment dataset.

The batch experiment further suggested that other amendments may be suitable for reduction of DTPA-extractable $\mathrm{Cd}$, but their effects may vary according to the soil type. However, there were only two replicates per treatment and they presented important variations. Therefore, at this point, amendments cannot be securely classified according to their efficiency to reduce the DTPA-extractable pool of the two investigated soils.

There are potentially a large number of amendments that may be efficient at reducing $\mathrm{Cd}$ concentration in tobacco leaves, depending on soil type. Synthetic compounds are usually more efficient because they are purer than natural ones. Pitcher et al. (2004) found that synthetic zeolites were more efficient than natural ones at removing $\mathrm{Zn}, \mathrm{Cd}, \mathrm{Cu}$ and $\mathrm{Pb}$ from motorway stormwater. In our pot experiment this may partially explain the good efficiency of hydroxyapatite at reducing $\mathrm{Cd}$ uptake by tobacco plants. However, the price, availability and composition of synthetic compounds may be the main limitation to their use on a large scale. Our aim was indeed to test easily available and cheap amendments to be used worldwide because commercial tobacco growing is performed on all continents (except Antarctica). This precluded synthetic amendments and orientated our choice towards natural and common compounds. For other reasons biosolids, which are known to achieve significant reduction in Cd availability to plants (Sterrett et al., 1996; Basta et al, 2001; Walker et al., 2003), were not tested in pots. Indeed, their efficiency may vary largely from one place to another and with time because of variation in their composition or processing, requiring a systematic and permanent quality control. Moreover, the origin of their sorption efficiency is not clearly established (Merrington and Smernik, 2003) and might decrease with time through decomposition of the organic matter (McBride, 1995), although the inorganic residue is also often claimed to be the active immobilising fraction in biosolids (Brown et al., 1998). In addition, owing to the large amounts needed, transport over large distances may not be cost efficient.

Keeping this in mind, soil Cd immobilisation using soil amendments appears to be an easy, relatively inexpensive and flexible approach that may be suitable for application in agricultural soils with low $\mathrm{Cd}$ concentrations. This approach would deserve further in depth research in order to adapt it to the large panel of soils cultivated with tobacco worldwide.

\section{Acknowledgements}

We thank Manuel Pérez-Gonzalez (TOLSA S.A., Spain) who provided sepiolite and information on this amendment, David Slater (Slater UK Limited) for providing apatite $\mathrm{II}^{\mathrm{TM}}$ and information on this amendment, J.-C. Buchs (HOLCIM, Eclepens, VD) for supplying the cement flour, Ets Desarzens, (Pomy, VD) for supplying the pots, Rolf Herzig (ABG, Bern) for supplying the Rafz soil, Gernot Alber (SOTA, Payerne) for help in supplying the Payerne soil and for agronomic advice, Matthias Meier (Philip Morris International, Lausanne) for advice on plant cultivation, and Ferruccio Gadani (Philip Morris International, Neuchâtel) for helpful comments on this manuscript. X-Ray fluorescence analyses were performed at the Institute of Terrestrial Ecology, ETH-Zürich. This research was supported by Philip Morris International and Ecole Polytechnique Fédérale de Lausanne.

\section{References}

Adamu C A, Mulchi C and Bell P F 1989 Relationships between $\mathrm{pH}$, clay, organic matter and $\mathrm{CEC}$ and heavy metal concentrations in soils and tobacco. Tob. Sci. 33, 96-100.

Adriano D C 2001 Trace elements in terrestrial environments: Biogeochemistry, bioavailability and risks of metals. Springer-Verlag, New York Inc, NY. 867 pp.

Alloway B J 1995 Heavy metals in soils. Blackie Academic \& Professional, Glasgow UK. 368 pp.

Alvarez-Ayuso E and García-Sanchez A 2003 Sepiolite as feasible soil additive for the immobilisation of cadmium and zinc. Sci. Tot. Environ. 305, 1-12.

Baize D and Sterckeman T 2001 Of the necessity of knowledge of the natural pedo-geochemical background content in the evaluation of the contamination of soils by trace elements. Sci. Tot. Environ. 264, 127-139. 
Basta N T, Gradwohl R, Snethen K L and Schroder J L 2001 Chemical immobilization of lead, zinc, and cadmium in smelter-contaminated soils using biosolids and rock phosphate. J. Environ. Qual. 30, 1222-1230.

Benedetti M F, VanRiemsdijk W H, Koopal L K, Kinniburgh D G, Gooddy D C and Milne C J 1996 Metal ion binding by natural organic matter: from the model to the field. Geochem. Cosmochim. Acta 60, 2503-2513.

Boisson J, Mench M, Sappin-Didier V, Solda P and Vangronsveld J 1998 Short-term in situ immobilization of Cd and $\mathrm{Ni}$ by beringite and steel shots application to long-term sludged plots. Agronomie 18, 347-359.

Boisson J, Ruttens A, Mench M and Vangronsveld J 1999 Evaluation of hydroxyapatite as a metal immobilizing soil additive for the remediation of polluted soils. Part 1 . Influence of hydroxyapatite on metal exchangeability in soil, plant growth and plant metal accumulation. Environ. Poll. 104, 225-233.

Brigatti M F, Medici L, Poppi L, Stewart A and Franchini G C 1998 Behaviour of sepiolite in $\mathrm{Co}^{2+} \mathrm{Cu}^{2+}$ and $\mathrm{Cd}^{2+}$ removal from a simulated pollutant solution. Ann. Chim. 88, 461-470.

Brown S L, Chaney R L, Angle J S and Ryan JA 1998 The phytoavailability of cadmium to lettuce in long-term biosolids-amended soils. J. Environ. Qual. 27, 1071-1078.

Brown S L, Henry C L, Chaney R L, Compton H and DeVolder P S 2003 Using municipal biosolids in combination with other residuals to restore metal-contaminated mining areas. Plant Soil 249, 203-215.

Brümmer G W, Gerth J and Tiller K G 1988 Reaction kinetics of the adsorption and desorption of nickel, zinc and cadmium by goethite. I. Adsorption and diffusion of metals. J. Soil Sci. 39, 37-52.

Chlopecka A and Adriano D C 1997 Influence of zeolite, apatite and $\mathrm{Fe}$-oxide on $\mathrm{Cd}$ and $\mathrm{Pb}$ uptake by crops. Sci. Tot. Environ. 207, 195-206.

Didier V, Mench M, Gomez A, Manceau A, Tinet D and Juste C 1993 Rehabilitation of cadmium-contaminated soils: efficiency of some inorganic amendments for reducing Cdbioavailability. CR Acad. Sci. Paris (série III) 316, 83-88.

di Toppi L and Gabbrielli R 1999 Response to cadmium in higher plants. Environ. Exp. Bot. 41, 105-130.

Dubois J-P, Okopnik F, Benitez N and Védy J-C 1998 Origin and spatial variability of cadmium in some soils of the Swiss Jura. Proceedings of the 16th World Congress on Soil Science, Montpellier, France.

FAL (Eidgenössische Forschungsanstalt für Agrarökologie und Landbau) 1998 Manuel pour l'analyse des sols, des plantes et de l'eau de percolation lysimétrique. Les Cahiers de la FAL 27, Zürich-Reckenholz, Switzerland, 227 pp.

Grant CA and Bailey L D 1993 Interactions of zinc with banded broadcast phosphorus fertilizer on the concentration and uptake of $\mathrm{P}, \mathrm{Zn}, \mathrm{Ca}$, and $\mathrm{Mg}$ in plant tissue of oilseed flax. Can. J. Plant Sci. 73, 17-29.

Gworek B 1992 Inactivation of cadmium in contaminated soils using synthetic zeolites. Environ. Poll. 75, 269-271.

Hartley W, Edwards R and Lepp N W 2004 Arsenic and heavy metal mobility in iron oxide-amended contaminated soils as evaluated by short- and long-term leaching tests. Environ. Poll. 131, 495-504.

Hiller D A and Brümmer GW 1997 Mikrosondenuntersuchungen an unterschiedlich stark mit Schwermetallen belasteten Böden. 2. Gehalte an Schwermetallen und anderen Elementen in Huminstoffaggregationen, Streustoffen und Holzkohlepartikeln. Z. Pflanzenernährung Bodenk. 160, 47-55.
Hodson M E, Valsami-Jones E and Cotter-Howells J D 2000 Bonemeal additions as a remediation treatment for metal contaminated soil. Environ. Sci. Technol. 34, 3501-3507.

Illera V, Garrido F, Serrano S and García-González M T 2004 Immobilization of the heavy metals $\mathrm{Cd}, \mathrm{Cu}$ and $\mathrm{Pb}$ in an acid soil amended with gypsum- and lime-rich industrial byproducts. Eur. J. Soil Sci. 55, 135-145.

Jamode A V, Rao M, Chandak B S, Jamode V S and Parwate A V 2003 Applications of the inexpensive adsorbents for the removal of heavy metals from industrial wastewater: a brief review. J. Ind. Poll. Control 19, 114-134.

Kaplan D I and Knox A S 2004 Enhanced contaminant desorption induced by phosphate mineral additions to sediment. Environ. Sci. Technol. 38, 3153-3160.

Kayser A 2000 Evaluation and enhancement of phytoextraction of heavy metals from contaminated soils. Dissertation ETH No. 13563 Swiss Federal Institute of Technology Zürich, Switzerland, pp. 27-54.

Keller C, Hammer D, Kayser A, Richner W, Brodbeck M and Sennhauser M 2003 Root development and phytoextraction efficiency: comparison of different species. Plant Soil 249, $67-81$

Kinniburgh DG, van Riemsdijk W H, Koopal L K, Borkovec M, Benedetti M F and Avena M J 1999 Ion binding to natural organic matter: competition, heterogeneity, stoichiometry and thermodynamic consistency. Coll. Surf. APhysicochem. Eng. Aspects 151, 147-166.

Knox A S, Kaplan D I, Adriano D C, Hinton T G and Wilson M D 2003 Apatite and phillipsite as sequestering agents for metals and radionuclides. J. Environ. Qual. 32, 515-525.

Knox A S, Seaman J C, Mench M and Vangronsveld J 2001 Remediation of Metal- and Radionuclides-Contaminated Soils. In Environmental Restoration of Metals-Contaminated Soils. Ed. IK Iskandar. pp. 21-60. CRC Press LLC, Boca Raton Florida.

Koopal L K, van Riemsdijk W H and Kinniburgh D G 2001 Humic matter and contaminants. General aspects and modeling metal ion binding. Pure Appl. Chem. 73, 2005-2016.

Krebs R, Gupta S K, Furrer G and Schulin R 1999 Gravel sludge as an immobilizing agent in soils contaminated by heavy metals; a field study. Water Air Soil Poll. 115, 465-479.

Li Y-M, Chaney R L, Schneiter A A and Johnson B L 1996 Effect of field limestone applications on cadmium content of sunflower (Helianthus annuus L.) leaves and kernels. Plant Soil 180, 297-302.

Lindsay W L and Norvell W A 1978 Development of a DTPA soil test for zinc, iron, manganese and copper. Soil Sci. Soc. Am. J. 42, 421-428.

Lombi E, Hamon R E, McGrath S P and McLaughlin M J 2003 Liability of $\mathrm{Cd}, \mathrm{Cu}$, and $\mathrm{Zn}$ in polluted soils treated with lime, beringite, and red mud and identification of a nonlabile colloidal fraction of metals using isotopic techniques. Environ. Sci. Technol. 37, 979-984.

Lombi E, Zhao F-J, Zhang G, Sun B, Fitz W, Zhang H and McGrath S P 2002 In situ fixation of metals in soils using bauxite residue: chemical assessment. Environ. Poll. 118, 435-443.

Lugon-Moulin N, Zhang M, Gadani F, Rossi L, Koller D, Krauss M and Wagner G J 2004 Critical review of the science and options for reducing cadmium in tobacco (Nicotiana tabacum L.) and other plants. Adv. Agron. 83, $111-180$. 
McBride M B 1995 Toxic metal accumulation from agricultural use of sludge: are USEPA regulations protective. J. Environ. Qual. 24, 5-18.

McBride M B and Martinez C E 2000 Copper phytotoxicity in a contaminated soil: remediation tests with adsorptive materials. Environ. Sci. Technol. 34, 4386-4391.

Matheson L J, Goldberg W C, Huddleston G J and Bostick W D 2002 Remediation of metal-contaminated soil and groundwater using apatite. Proceedings of the Third International Conference on Remediation of Chlorinated and Recalcitrant Compounds, pp. 2103-2110.

Mench M J, Didier V L, Löffler M, Gomez A and Masson P 1994 A mimicked in-situ remediation study of metalcontaminated soils with emphasis on cadmium and lead. J. Environ. Qual. 23, 58-63.

Mench M J and Martin E 1991 Mobilization of cadmium and other metals from two soils by root exudates of Zea mays L., Nicotiana tabacum L. and Nicotiana rustica L. Plant Soil 132, 187-196.

Mench M J, Tancogne J, Gomez A and Juste C 1989 Cadmium bioavailability to Nicotiana tabacum L., Nicotiana rustica L., and Zea mays L. grown in soil amended or not amended with cadmium nitrate. Biol. Fert. Soils 8, 48-53.

Merrington G and Smernik R J 2003 Cadmium sorption in biosolids amended soils: results from a field trial. Environ. Poll. 327, 239-247.

Miner G S, Gutierrez R and King L D 1997 Soil factors affecting plant concentrations of cadmium, copper, and zinc on sludge-amended soils. J. Environ. Qual. 26, 989-994.

Papadopoulos P and Rowell D L 1988 The reactions of cadmium with calcium carbonate surfaces. J. Soil Sci. 39 23-36.

Pitcher S K, Slade R C T and Ward NI Heavy metal removal from motorway stormwater using zeolites. Sci. Tot. Environ. 334-335:161-166.

Randall S R, Sherman D M and Ragnarsdottir K V 1999 The mechanism of cadmium surface complexation on iron oxyhydroxyde minerals. Geochim. Cosmochim. Acta 63, 2971-2987.

Richards B K, Steenhuis T S, Peverly J H and McBride M B 2000 Effect of sludge-processing mode, soil texture and soil $\mathrm{pH}$ on metal mobility in undisturbed soil columns under accelerated loading. Environ. Pollut. 109, 327-346.

Sappin-Didier V and Gomez A 1994 Réhabilitation des sols pollués par des métaux toxiques. Exemple de l'apport de grenaille de fer. Analusis Magazine 22, M28-M30.

Sappin-Didier V, Mench M, Gomez A and Lambrot C 1997 Use of inorganic amendments for reducing metal bioavailability to ryegrass and tobacco in contaminated soils. In Remediation of Soils Contaminated with Metals. Eds. I K Iskandar. \& D C Adriano. pp. 85-98. Science Reviews, Northwood.

Sauerbeck D 1989 Der Transfer von Schwermetallen in die Pflanze. In Beurteilung von Schwermetallkontaminationen im Boden. Fachgespräche Umweltschutz DECHEMA, Stuttgart am Mainz, Germany, pp. 281-316.
Skjemstad J, Janik L and Taylor J 1998 Non-living soil organic matter: what do we know about it? Austr. J. Exp. Agric. 38, 667-680.

Spadini L, Schindler P W, Charlet L, Manceau A and Ragnarsdottir K V 2003 Hydrous ferric oxide: evaluation of $\mathrm{Cd}-\mathrm{HFO}$ surface complexation models combining $\mathrm{Cd}_{\mathrm{K}}$ EXAFS data, potentiometric titration results, and surface site structures identified from mineralogical knowledge. J. Colloid Interface Sci. 266, 1-18.

Sterrett S B, Chaney R L, Gifford C H and Mielke H W 1996 Influence of fertilizer and sewage sludge compost on yield and heavy metal accumulation by lettuce grown in urban soils. Environ. Geochem. Health 18, 135-142.

Stipp S L, Hochella M F, Parks G A and Leckie J O 1992 Cd $^{2+}$ uptake by calcite, solid-state diffusion, and the formation of solid-solution: interface processes observed with near-surface sensitive techniques (XPS, LEED, and AES). Geochim. Cosmochim. Acta 56, 1941-1954.

Tsadilas C D 2000 Soil pH influence on cadmium uptake by tobacco in high cadmium exposure. J. Plant Nutr. 23, 1167-1178.

Tsadilas C D, Karaivazoglou N A, Tsotsolis N C, Stamatiadis $\mathrm{S}$ and Samaras V 2005 Cadmium uptake by tobacco as affected by liming, $\mathrm{N}$ form, and year of cultivation. Environ. Poll. 134, 239-246.

Vangronsveld J, Colpaert J V and van Tichelen K K 1996 Reclamation of a bare industrial area contaminated by nonferrous metals: physico-chemical and biological evaluation of the durability of soil treatment and revegetation. Environ. Poll. 94, 131-140.

Vangronsveld J and Cunningham S D 1998 Chapter 1. Introduction to the concept. In Metal-Contaminated Soils. Eds. J Vangronsveld. \& S D Cunningham. pp. 1-16. Springer-Verlag New York Inc., NY.

Wagner G J 1993 Accumulation of cadmium in crop plants and its consequences to human health. Adv. Agron. 51, 173-212.

Walker D J, Clemente R, Roig A and Bernal M P 2003 The effects of soil amendments on heavy metal bioavailability in two contaminated Mediterranean soils. Environ. Poll. 122, 303-312.

Walker D J, Clemente R and Bernal M P 2004 Contrasting effects of manure and compost on soil $\mathrm{pH}$, heavy metal availability and growth of Chenopodium album L. in a soil contaminated by pyritic mine waste. Chemosphere 57, 215-224.

Wang X-P, Shan X-Q, Zhang S-Z and Wen B 2004 A model for evaluation of the phytoavailability of trace elements to vegetables under the field conditions. Chemosphere 55, $811-822$.

World Health Organisation (WHO) 1992 Environmental Health Criteria 134 - Cadmium International Programme on Chemical Safety (IPCS) Monograph.

Zachara J M, Cowan C E and Resch C T 1991 Sorption of divalent metals on calcite. Geochim. Cosmochim. Acta 55, $1549-1562$.

Section editor: A.J.M. Baker 